\title{
COVID-19 and Microfinance Banks in Nigeria
}

\author{
Yetunde Tonia Ayeni ${ }^{1}$, Oludayo Elijah Adekunle ${ }^{2 *}$ \\ ${ }^{1}$ Department of Banking and Finance, Afe Babalola University, Km 8.5 Afe Babalola Way, Ado-Ekiti, \\ Ekiti State, Nigeria. \\ ${ }^{2}$ Department of Banking and Finance, Adekunle Ajasin University, P. M. B. 001, Akungba-Akoko, Ondo \\ State, Nigeria. \\ e-mail: adekunleoludayo864@yaoo.com
}

DOI: 10.51865/EITC.2021.04.04

\begin{abstract}
This study investigated the effects of COVID-19 pandemic on the activities and performance of microfinance banks with special focus on South West Region of Nigeria. Data were collected from 100 heads of department selected from 20 randomly picked microfinance banks. Data were analyzed with simple percentage and regression technique. It was discovered that, COVID-19 impedes the activities of microfinance banks through fall in loans repayment, declining deposits mobilization, low customers patronage, poor operational efficiency, and high nonperforming loans. The study concluded that, COVID-19 imposed constraints on the activities of microfinance banks which negatively affect financial performance. It was suggested that, there is need for quick response of regulatory authorities to microfinance banks. Financial and regulatory supports should be initiated to stop the declining activities of microfinance banks because microfinance banks play supporting role to small business and less privilege in the economy. There is need for the digitization of microfinance banks' activities to cushion the negative effects of future pandemic. Periodic review should be undertaken to monitor and uncover threats in the loan portfolios, liquidity position, and financial statements of MFBs for quick policy initiatives and innovations.
\end{abstract}

Keywords: COVID-19; financial sector; microfinance banks; pandemic.

JEL Classification: $G 2 ; G 18 ; G 21$.

\section{Introduction}

Since this century, several diseases have engendered the survival of human being. Of these diseases, the current Coronavirus Disease 2019 (COVID-19) has posed greater challenges to the health and existence of human globally (World Health Organization, 2020). COVID-19 significantly influences both national and world economy in a diverse ways and create greater impediment to the progress recorded in terms of growth and development by countries (Geda, 2020). This has thus generated a lot of debate and contributions from scholars, policy makers and world international organization.

\footnotetext{
${ }^{*}$ Corresponding author
} 
Financial sector has been greatly affected by the continuous rise of COVID-19. The pandemic which present sudden macroeconomic distress to financial system globally recently led to recession which has been experienced by different economy in the world. Important institutions which the pandemic affected are microfinance institutions. Microfinance institutions globally are faced with the difficulties of continually directing credit to small business and less privilege group of the economy despite falling economic activities while also managing rising risks (Financial Stability Board, 2020a).

The surge of COVID-19 has been forecasted to pose genuine challenges to the survival of microfinance banks. Islamic Development Bank (2020); Ogdenand Bull(2020) suggested that, microfinance banks that are only interested in providing finance may have the problem of surviving during the period of lockdown because the fall of loan repayment rates to 85 percent from 95 percent may pose insolvency challenges to majority of microfinance banks. Alshebami and Rengarajan (2020) opined that, default in loan repayment by borrowers due to COVID-19 will result in highly non-performing asset thereby negatively affecting operational activities of MFIs which may eventually lead to bankruptcy.

The pandemic has caused different problems to the activities of microfinance banks globally which include loan disbursement, recoupment of loan, physical meeting of clients, reorganization of organizational structure and flow of activities (Dąbrowska, Koryński and Pytkowska, 2020). These therefore have deteriorating effects on the portfolio and performance of microfinance institutions. However, it is believed that the severity and spread of COVID-19 have different influences on microfinance banks performance and activities at different region. Furthermore, the effects also depend on the forms of services that are provided by the banks and their level of internal structure (Zhen and Zhang, 2020).

While the performance of microfinance banks that accept savings and rely heavily on deposits to make loans especially in Sub-Saharan Africa regions were extremely impacted, microfinance institutions that are not permitted to take deposit especially in Europe are not highly impacted (Dąbrowska, et al., 2020). Also, institutions that make use of digital technologies were able continue rendering services and relating with clients by giving loans virtually, others that focus on the adoption of traditional methods in relating with customers and rely on physical meeting with clients are severely impacted by the restrictions imposed on mobility as a result of the pandemic. This was the case for many MFIs in Latin and Central America, Central Asia, and the MENA region but to a much lesser degree for MFIs in South East Asia or Sub-Saharan Africa.

However, although studies have focused on the effect of COVID-19 pandemic on the activities of microfinance banks in some countries, almost no study has been conducted on how the pandemic influence the performance of microfinance banks in Nigeria. In Nigeria, microfinance banks face more severe challenges than commercial banks due to their weaker financial position and are more exposed to loan portfolio corrosion which put MFBs earning capacity and future in danger. With lack of adequate digital capacities to continue interacting with clients and agents which imposed constraints on their performance and insufficient capital, they face significant liquidity threat in a post pandemic era which may negatively affects their survival and the small-scale businesses that they serve. The lack of attention on the effect COVID-19 pandemic on microfinance banks in Nigeria is regrettable, because MFBs support large proportion of the poor, small-scale businesses and vulnerable people in Nigeria and other developing countries. Thus this study filled the gap in literature by investigating the effects of COVID-19 pandemic on the activities of microfinance banks and financial performance in South West Region of Nigeria. The rest of the paper is divided into literature review, methodology, presentation of results and conclusion. 


\section{Literature Review}

\section{Post-COVID-19 pandemic threats}

The severity of COVID-19 on financial institutions and markets serves as a major concern to different stakeholders globally. Without doubt, post-COVID-19 pandemic is expected to impose grater constraints on globally economy and financial system with different actions and policy frameworks to mitigate these constraints expected to face some setbacks (World Economy Forum, 2020). Globally, financial markets have experienced price re-adjustment due to COVID19 epidemic. Incessant nose-diving and deterioration expected economic activities acerbated by risk intolerance and doubt of future pandemic have resulted in uncertainty regarding business activities and expectation of capital flow in emerging marketing and exchange rates instability (Financial Stability Board, 2020a). Most of financial distress indicators of financial institutions especially microfinance banks have continued to rise sharply (Schulte and Winkle, 2019).

Microfinance banks and other financial institutions globally are under pressure resulting from excess demand for funds by business sector to reinvigorate business activities. There is considerably shock in market activities and price innovation, which is expected to affect liquidity position of financial markets and institutions (Bartik, Bertrand, Cullen, Glaeser, Luca and Stanton, 2020). Nevertheless, following the adoption of expansionary macroeconomic policies, some distress indices are subdued. While major financial institutions are strong and stable despite uncertainty and pressure resulting from the pandemic, microfinance banks especially in developing countries are still negatively affected (Financial Stability Board, 2020b).

However, in spite of the steps initiated to curb the COVID-19 pandemic, there are still problem of liquidity crisis which may affect microfinance institutions (World Economy Forum, 2020). Globally, microfinance institutions are still threatened by liquidity and vulnerability due to falling economic activities especially among small and medium businesses. This worsening economic activities, has resulted in high credit default, and low deposit mobilization capacity (World Economy Forum, 2020).

There are high rate of underperformance in loan portfolios and increase in exposure to nonperforming loans by financial and non-financial institutions. Microfinance banks that are not capable of meeting the loan demand of the productive and other important sectors as result of fall in deposit mobilization capacity occasioned by the COVID-19 epidemic are expected to witness significant fall in earnings capacity. As a result of this, small and medium scale enterprises who rely heavily on loans from microfinance banks may be negatively affected (Financial Stability Board, 2020c).

\section{Empirical review}

Microfinance banks are different from commercial banks because of the unique role in terms of financial sustainability and social outreach. They give microcredit without collateral to lowincome groups and small-scale businesses that are unable to access credit and other financial services from formal financial intuitions (Zamore, Beisland and Mersland, 2019). Microfinance banks play important role in alleviating poverty in developing countries because they render services to millions of vulnerable and poor people. Microfinance banks also have the objective of making profit or breaking-even like other profit driven organizations (Armendáriz and Morduch, 2010). Thus, microfinance banks are assessed in line with their social impact and profit-making efficiency.

However, despite the importance of microfinance banks in the economy, their performance can be influenced by economic and natural crisis. Studies have suggested that economic depression that is caused by pandemic will impose pressure on the loan portfolios of banks which may 
result in withdrawal of depositors' funds especially in developing countries (Beck, 2020; Lagoarde-Segot and Leoni, 2013; Field, Pande, Papp and Rigol, 2013). Thus, it is expected that the socio-economic harm induced by COVID-19 pandemic may influence the financial performance of microfinance banks negatively. Foremost, the failure of small-scale businesses and less privilege household to repay debt caused by COVID-19 will lead to weakening of microfinance banks performance. The pandemic will bring about cash strap to businesses due low cash flow to service debt collected as result of shutdown of machines, disruption in supply chain and unexpected decline in the demand for goods and services (Ogden and Bull, 2020). In addition, fall in economic and productive activities generally transmutes to rise in unemployment rate which result in inability of laid-off employers to meet up with their financial obligations to microfinance banks performance thereby leading to increase in nonperforming loans and fall in performance (Skoufias, 2003). Subsequent rising non-performing loans due to COVID-19 shock will affect the confidence of depositors' thereby leading to high withdrawals of deposits and banking run (Beck, 2020).

Fidow (2020) investigated impact of COVID-pandemic on loan repayment of small enterprises in Eastleigh business community. The study randomly sampled 50 respondents analyzed with descriptive statistics, regression and correlation technique. It was found that there is significant and negative relationship between COVID-19 pandemic and loan repayment by small businesses in Easteigh.

Ivanov (2020) studied the effect of pandemic outbreaks on supply chains globally. The study adopted logistic and simulation technique and it was revealed that opening and closing time of businesses impede supply chain performance due to pandemic outbreak.

Fernandes (2020) examined the effect economic effects of corona virus outbreak on the world economy through the sampling of 30 countries. The study indicated that that GDP growth will decline by either 3 or $6 \%$ base on the specific country. It was also revealed that GDP will fall by $15 \%$ in countries that are exercising severe outbreak and economic lockdown.

Dąbrowska, et al., (2020) analyzed the effect of COVID-19 pandemic on the microfinance sector in Europe. The study based it analysis on data collected by Microfinance Centre (MFC) through a survey of microfinance institutions across Europe. The study found that though the epidemic affected all counties in Europe, the extent of the impact depends on the nature and strangeness of the country. Also, it was established that the lockdown imposed by countries to contain the pandemic influence microfinance banks and their clients negatively.

Zheng and Zhang (2020) in their study assessed how COVID-19 affects the efficiency of financial and social efficiency of microfinance institutions as a result of decline in economic activities. Using Data Envelopment Analysis (DEA) framework on data collected from global data base of microfinance banks and Asian Development Bank (ADB), it was indicated that the pandemic had negative effect on financial efficiency of MFIs, though with positive impact on the social efficiency of MFIs.

\section{Methodology}

Based on the nature of this research, survey design was adopted to gather data from the respondents through questionnaire from which conclusion and recommendations were drawn. The population consisted of the staff of microfinance banks operating in South West Region, Nigeria. The study relied on primary data sourced from staff of the selected banks with the aid of questionnaire. 20 microfinance banks were randomly selected from South West Region, Nigeria. The microfinance banks were mainly located in cities. The banks were selected due to their high level of activities and size in terms of assets, customer base and popularity. Thus, the sample was made of 100 staff that are heads of different department in the banks. Heads of department were selected because they possess important information regarding the activities of 
the selected banks during the COVID-19 pandemic and they are always present at the banks during the lockdown period. Therefore, 5 staff were randomly selected from each bank which amount to 100 respondents.

The research instrument (questionnaire) was designed to elicit respondents view on the effect of COVID-19 on the financial performance of microfinance banks in West Region, Nigeria. The research instrument is a four Likert scale point of Strongly Agreed (SA), Agreed (A), Disagreed (D) and Strongly Disagreed (SD). Collected data were presented in table to show the responses of respondents to the questions. Simple percentage and frequency are used to analyze the data collected while regression technique was employed to test the significance of the variable parameters.

\section{Results and Discussions}

Table 1 presents result on the demographic information of the respondents. Based on gender, it is revealed that 64 of the respondents are male while $36 \%$ of the respondents are female. Based on education quality, $28 \%$ of the respondents are OND certificate holder, $45 \%$ are $\mathrm{HND} / \mathrm{BSC}$ certificate holder while $27 \%$ of the respondents are MSC/PHD certificate holder. Based on types of department of the respondents, $23 \%$ of the respondents are operating in credit department, $25 \%$ are operating in customer service department, $28 \%$ are operating in marketing department while $24 \%$ are operating in audit and accounting department. Finally, the result presented in Table 1 shows that $15 \%$ of the respondents have below 4 years working experience, $26 \%$ have between 5-10 years working experience, 39\% have 11-14 years working experience while $20 \%$ of the respondents have above 15 years working experience.

Table 1. Respondents Information

\begin{tabular}{|l|l|l|}
\hline Gender: & Frequency & Percentage \\
\hline Male & 64 & $64 \%$ \\
\hline Female & 36 & $36 \%$ \\
\hline Educational Qualification: & Frequency & Percentage \\
\hline OND & 28 & $28 \%$ \\
\hline HND/B.Sc. & 45 & $45 \%$ \\
\hline M.Sc. /PhD & 27 & $27 \%$ \\
\hline Departments: & Frequency & Percentage \\
\hline Credit Department & 23 & $23 \%$ \\
\hline Customer Service Department & 25 & $25 \%$ \\
\hline Marketing Department & 28 & $28 \%$ \\
\hline Audit and Accounting Department & 24 & $24 \%$ \\
\hline Working Pexreience: & Frequency & Percentage \\
\hline Below 4 years & 15 & $15 \%$ \\
\hline 5-10 years & 26 & $26 \%$ \\
\hline $11-14 y e a r s$ & 39 & $39 \%$ \\
\hline 15 years and above & 20 & $20 \%$ \\
\hline
\end{tabular}

Source: Authors' field survey, 2021.

The presented in Table 2 shows the responses of head of departments to questions on the implication of COVID-19 on microfinance banks institutions in South Western Region of Nigeria. The result in item 1 shows that $56 \%$ and $30 \%$ of the respondents strongly agreed and agreed respectively that COVID-19 affect the activities of microfinance banks while $14 \%$ of the respondents disagreed that COVID-19 affect the activities of microfinance banks. In Item 2, $37 \%$ and $45 \%$ of the respondents strongly agreed and agreed respectively that COVID-19 increases nonperforming loans of microfinance banks while $18 \%$ are of the opinion that COVID-19 does not increase nonperforming loans of microfinance banks. Item 3 shows that 
$54 \%$ and $46 \%$ of the sampled respondents are of the opinion that Do you COVID-19 pandemic affect the operational efficiency of microfinance banks in a negative way.

Table 2. Questions on the implications of COVID-19 on microfinance activities and performance

\begin{tabular}{|c|c|c|c|c|c|}
\hline $\mathrm{S} / \mathbf{N}$ & Questions & SA & AG & DG & SD \\
\hline 1. & $\begin{array}{l}\text { Does COVID- } 19 \text { in anyway affect the activities of } \\
\text { microfinance banks? }\end{array}$ & $56(56 \%)$ & $30(30 \%)$ & $14(14 \%)$ & - \\
\hline 2. & $\begin{array}{l}\text { Does COVID-19 increase nonperforming loans of } \\
\text { microfinance banks? }\end{array}$ & $37(37 \%)$ & $45(45 \%)$ & - & $18(18 \%)$ \\
\hline 3. & $\begin{array}{l}\text { Do you think that the pandemic affects the operational } \\
\text { efficiency of microfinance banks in a negative ways? }\end{array}$ & $54(54 \%)$ & $46(46)$ & - & - \\
\hline 4. & $\begin{array}{l}\text { Does COVID-19 pandemic induce decline in the cash } \\
\text { flow of microfinance banks? }\end{array}$ & $47(47 \%)$ & $36(36 \%)$ & $10(10 \%)$ & $7(7 \%)$ \\
\hline 5. & $\begin{array}{l}\text { Do you think that COVID-19 reduce the deposits } \\
\text { being mobilized by microfinance banks? }\end{array}$ & $43(43 \%)$ & $47(47 \%)$ & $5(5 \%)$ & $5(5 \%)$ \\
\hline 6. & $\begin{array}{l}\text { Does lockdown induced by COVID-19 pandemic } \\
\text { leads to low patronage of microfinance banks by } \\
\text { customers? }\end{array}$ & $51(51 \%)$ & $49(49 \%)$ & - & - \\
\hline 7. & $\begin{array}{l}\text { The recession caused by COVID-19 pandemic results } \\
\text { in inability of debtors to settle microcredit debts } \\
\text { resulting in high rate of nonperforming of } \\
\text { microfinance banks. }\end{array}$ & $33(33 \%)$ & $49(18 \%)$ & $18(18 \%)$ & \\
\hline 8. & $\begin{array}{l}\text { Does COVID-19 pandemic negatively affect the } \\
\text { revenue of microfinance banks? }\end{array}$ & $46(46 \%)$ & $41(41 \%)$ & $13(13 \%)$ & - \\
\hline 9. & $\begin{array}{l}\text { Microfinance banks profitability declines due to } \\
\text { COVID-19 pandemic }\end{array}$ & $42(42 \%)$ & $43(43 \%)$ & $10(10 \%)$ & $(5 \%)$ \\
\hline 10. & $\begin{array}{l}\text { Does COVID- } 19 \text { pandemic imposes constraint on the } \\
\text { performance of microfinance banks? }\end{array}$ & $46(46 \%)$ & $49(49 \%)$ & $5(5 \%)$ & - \\
\hline
\end{tabular}

Source: Authors' field survey, 2021.

In response to question in item 4 it is revealed that, majority of the respondents representing $47 \%$ and 36\% accepted that COVID-19 pandemic induces decline in the cash flow of microfinance banks while 10\% and 7\% disgraced that COVID-19 pandemic induces decline in the cash flow of microfinance banks. Furthermore in Item 5, 43\% and $47 \%$ of the respondents agreed that COVID-19 reduces the deposits mobilization capacity of microfinance banks while $10 \%$ of the respondents degreed that COVID-19 reduces the deposits mobilization capacity of microfinance banks. The result in item 6 reveals that $51 \%$ and $49 \%$ of the respondents are of the opinion that lockdown induces by COVID-19 pandemic leads to low patronage of microfinance banks by customers.

The result in item 7 reported in Table 2 shows that, $33 \%$ and $49 \%$ of the respondents asserted that the recession caused by COVID-19 pandemic results in inability of debtors to settle microcredit debts resulting in high rate of nonperforming of microfinance banks while $18 \%$ of the respondents go in contrary to this assertion. In item $8,46 \%$ and $41 \%$ of the respondents agreed that COVID-19 pandemic negatively affect the revenue of microfinance banks while $13 \%$ of the respondents disagreed. Furthermore in item $9,42 \%$ and $43 \%$ of the respondents are of the opinion that microfinance banks profitability declines due to COVID-19 pandemic while $10 \%$ and $5 \%$ of the respondents disagreed with this assertion. Finally in item $10,46 \%$ and $49 \%$ of the respondents assert that COVID-19 pandemic imposes constraint on the performance of microfinance banks while $5 \%$ of the respondents disagreed. 


\section{Regression Results}

Table 3 presents the regression result on the effect of microfinance banks activities (MFBA) affected by COVID-19 on the financial performance of microfinance banks. The result revealed that microfinance banks activities (MFBA) affected by COVID-19 has negative and significant effect on financial performance of microfinance banks with a coefficient of -5.346. This implies that COVID-19 imposed constraints on the activities of microfinance banks activities which negatively affect their financial performance.

Table 3. Coefficients

\begin{tabular}{|l|c|c|c|c|}
\hline \multicolumn{1}{|c|}{ Variables } & Coefficients & Standard Error & t-statistics & Probability \\
\hline (Constant) & 8.483 & 1.063 & 7.980 & 0.000 \\
\hline MFBA COVID-19 & -5.346 & 2.154 & -4.114 & 0.010 \\
\hline R-Square & 0.734 & & & \\
\cline { 1 - 2 } Adjusted R Square & 0.622 & & & \\
\cline { 1 - 2 } F-Statistic & 16.713 & & & \\
Probability & 0.0000 & & & \\
\cline { 1 - 1 } Durbin-Watson & 1.807 & & & \\
\cline { 1 - 2 }
\end{tabular}

Source: Authors' field survey, 2021.

The adjusted $\mathrm{R}$ Square value of 0.622 or $62.2 \%$ implies that $62.2 \%$ variation in financial performance of microfinance banks are caused by COVID-19 pandemic. The F-statistic value is given as 16.713 with a corresponding significance value of 0.000 which is significant at $5 \%$. This implies that COVID-19 has significant effect on the financial performance of microfinance banks. Finally, the Durbin- Watson value of 1.807 entails the absence of auto correlation in the result since the Durbin-Watson value is close to 2.

\section{Conclusion}

This study investigated the effects of COVID-19 on the financial performance of microfinance banks in South West Region of Nigeria. The study focused on 20 randomly selected microfinance banks located in cities while 100 heads of department were sampled. Data collected through questionnaires were analyzed with simple percentage and regression technique. It was revealed that COVID-19 imposed constraints on the activities of microfinance banks which negatively affect financial performance. It was established that COVID-19 impedes the activities of microfinance banks through loans repayment, deposit mobilization, customers, patronage, operational efficiency, and nonperforming loans. These results were supported by the empirical findings of Zheng and Zhang (2020); Dąbrowska, et al., (2020) who established negative effects of COVID-19 on the operational efficiency, activities and performance of microfinance banks. The study suggested quick response of regulatory authorities to microfinance banks during the post COVID-19 period. Financial and regulatory supports should be given to declining microfinance banks because microfinance banks play supporting role to small business and less privilege in the economy. There is need for the digitization of microfinance banks activities to cushion the negative effects of future pandemic. The stability of microfinance banks must be cautiously and swiftly managed because further crisis which may occurred in a post pandemic period may expose them to unknown and unexpected weaknesses, especially the microfinance banks at local and state level. Periodic review should be undertaken to monitor and uncover threats in the loan portfolio, liquidity position, and financial statements of MFBs for quick policy initiatives and innovations. 


\section{References}

1. Alshebami, A.S. and Rengarajan, V., 2020. An imperative need for a new social order in microfinance community - Towards ushering in a resilient eco-system in the battle against corona pandemic. International Journal of Research, 8(08), 107 - 123.

2. Armendáriz, B. and Morduch, J., 2010. The economics of microfinance. MIT press.

3. Bartik, A.W., Bertrand, M., Cullen, Z.B., Glaeser, E.L., Luca, M. and Stanton, C. T., 2020. How are small businesses adjusting to covid-19? Early evidence from a survey. Working Paper 26989, National Bureau of Economic Research.

4. Beck, T., 2020. Finance in the times of coronavirus. In R. Baldwin and B. W. di Mauro (Eds.), Economics in the time of COVID-19, a VoxEU.org eBook. CEPR Press.

5. Dąbrowska, K., Koryński, P. and Pytkowska, J., 2020. Impact of COVID-19 pandemic on the microfinance sector in Europe: Field analysis and policy recommendations. www.mfc.org.pl/covid19.

6. Fernandes, N., 2020. Economic effects of coronavirus outbreak (COVID-19) on the world economy. Available at SSRN 3557504.

7. Fidow, A.N., 2020. Effect of Covid-19 on loan repayment of small businesses in Kenya: A case study of Eastleigh business community. European Journal of Business and Strategic Management, 5(2), $1-14$.

8. Field, E., Pande, R., Papp, J., and Rigol, N., 2013. Does the classic microfinance model discourage entrepreneurship among the poor? experimental evidence from India. American Economic Review, 103(6):2196-2226.

9. Financial Stability Board, 2020a. COVID-19 pandemic: Financial stability implications and policy measures taken. Report submitted to the G20 Finance Ministers and Governors. Available through: https://www.fsb.org/wp-content/uploads/P150720-2.pdf.

10. Financial Stability Board, 2020b. COVID-19 pandemic: Financial stability implications and policy measures taken. Available through: https://www.fsb.org/wp-content/uploads/P150420.pdf.

11. Financial Stability Board, 2020c. FSB coordinates financial sector work to buttress the economy in response to COVID-19, 20 March 2020. Available through: https://www.fsb.org/2020/03/?policy_area=covid-19.

12. Geda, A., 2020. The macroeconomic and social impact of COVID-19 in Ethiopia and suggested directions for policy response. Addis Ababa University.

13. Islamic Development Bank, 2020. The Covid-19 crisis and Islamic finance. Available through: https://www.isdb.org/sites/default/files/media/documents/202010/1.\%20IsDB\%20Group\%20Report $\% 20$ on\%20Covid-19\%20and\%20Islamic\%20Finance_FINAL.pdf.

14. Ivanov, D., 2020. Predicting the impacts of epidemic outbreaks on global supply chains: A simulation-based analysis on the coronavirus outbreak (COVID-19/SARS-CoV-2) case. Transportation Research Part E: Logistics and Transportation Review, 136, 101922.

15. Lagoarde-Segot, T. and Leoni, P.L., 2013. Pandemics of the poor and banking stability. Journal of Banking \& Finance, 37(11), 4574-4583.

16. Ogden, T. and Bull, G., 2020. COVID-19: How does microfinance weather the current storm. Available through: https://www.financialaccess.org/blog/2020/3/26/covid-19-how-does microfinance-weather-the-current-storm.

17. Schulte, M. and Winkler, A., 2019. Drivers of solvency risk-Are microfinance institutions different? Journal of Banking \& Finance, 106:403-426.

18. Skoufias, E., 2003. Economic crises and natural disasters: Coping strategies and policy implications. World Development, 31(7), 1087-1102.

19. Zamore, S., Beisland, L.A. and Mersland, R., 2019. Geographic diversification and credit risk in microfinance. Journal of Banking \& Finance, 109, Article 105665.

20. Zhen, C. and Zhang, J., 2020. The impact of COVID-19 on the efficiency of microfinance institutions. International Review of Economics and Finance, 71, 407-423. 